\title{
SISTEM MONITORING VOLUME LIFTING MINYAK DAN GAS BUMI BERBASIS SCADA (SUPERVISORY CONTROL AND DATA ACQUCITION) PADA PT. ASTRON OPTIMA
}

\author{
Haerudin
}

\author{
Sistem Informasi \\ STMIK Nusa Mandiri \\ www.nusamandiri.ac.id \\ aerudinraw@gmail.com
}

\begin{abstract}
During this time the community can control things from a distance by using a remote control, but the control is hampered by distance. If the distance between the controlled device and the controller exceeds the tolerance limit, the equipment cannot function as desired. In addition, there are also constraints on costs for distance. The longer the distance the greater the cost of the pulses issued. The problem that often arises is the difference in parameters possessed by the KKKS including the character of data filling. The problem that often arises is the difference in parameters possessed by the KKKS including the character of data filling. Especially for KKKS with oil products there is flushing which should not be included as a lifting volume. The value of flushing is different for each KKKS so it is necessary to equalize the perception with the KKKS regarding the procedure for recording data including the time of filling in the database. There is still a time difference at the CTP point, the time at the Poller Migas Control Center and the time in the Database Server so that there is a partial data flowrate that has been filled but has not yet been displayed on the web. The purpose of this study is to increase the effectiveness and efficiency of business management and trade in oil and gas, especially in terms of monitoring the volume of oil and gas lifting. Installation of a monitoring system that is an integration of a number of software applications, hardware and a number of procedures that are capable of verifying and tracking the truth of the lifting volume reports submitted by the KKKS.
\end{abstract}

Keywords: SCADA, Supervisory Control and Data Acqucition, Oil and Gas Lifting Volume Monitoring System

Abstrak

Selama ini masyarakat dapat mengontrol sesuatu dari jarak jauh dengan menggunakan remote control, akan tetapi pengontrolan tersebut terhambat oleh jarak. Apabila jarak antara alat yang dikontrol dengan pengontrol itu melewati batas toleransinya, maka peralatan tersebut tidak dapat berfungsi sesuai dengan yang diinginkan. Selain itu juga adanya kendala biaya terhadap jarak. Jarak semakin jauh maka biaya pulsa yang dikeluarkan semakin besar. Permasalahan yang sering muncul yaitu perbedaan parameter yang dimiliki KKKS termasuk karakter pengisisan data. Permasalahan yang sering muncul yaitu perbedaan parameter yang dimiliki KKKS termasuk karakter pengisisan data. Khusus untuk KKKS dengan produk minyak terdapat flushing yang seharusnya tidak dimasukkan sebagai volume lifting. Nilai flushing ini berbeda-beda untuk tiap KKKS sehingga perlu penyamaan persepsi dengan KKKS tentang tata cara recording data termasuk waktu pengisian database. Masih terdapat perbedaan waktu di titik CTP, waktu di Poller Migas Control Center dan waktu di Database Server sehingga ada sebagian data flowrate yang terisi tetapi belum sempat ditampilkan di web. Tujuan dari penelitian ini untuk peningkatan efektifitas dan efisiensi pengelolaan usaha dan tata niaga minyak dan gas bumi, khususnya dalam hal monitoring volume lifting minyak dan gas bumi. Pemasangan sistem monitoring yang merupakan integrasi dari sejumlah aplikasi perangkat lunak, perangkat keras serta sejumlah prosedur yang mampu melakukan verifikasi serta penelusuran terhadap kebenaran laporan volume lifting yang disampaikan oleh pihak KKKS

Kata Kunci: SCADA, Supervisory Control and Data Acqucition, Sistem Monitoring Volume Lifting Minyak dan Gas Bumi 


\section{PENDAHULUAN}

Inovasi di dalam teknologi telekomunikasi berkembang dengan cepat dan selaras dengan perkembangan karakteristik masyarakat modern yang memiliki mobilitas tinggi, mencari layanan yang fleksibel, serba mudah dan memuaskan serta mengejar efisiensi di segala aspek. Kebutuhan akan sistem untuk pengendalian jarak jauh semakin meningkat sejalan dengan era globalisasi dimana perpindahan dan pergerakan manusia semakin luas dan cepat. Selama ini masyarakat dapat mengontrol sesuatu dari jarak jauh dengan menggunakan remote control, akan tetapi pengontrolan tersebut terhambat oleh jarak. Apabila jarak antara alat yang dikontrol dengan pengontrol itu melewati batas toleransinya, maka peralatan tersebut tidak dapat berfungsi sesuai dengan yang diinginkan.

Pengontrolan melalui jalur telepon merupakan hal yang lumrah, tetapi sistem ini kerap digunakan untuk sistem fix-point to point. Selain itu juga adanya kendala biaya terhadap jarak. Jarak semakin jauh maka biaya pulsa yang dikeluarkan semakin besar. Teknologi jaringan komputer merupakan solusi yang dapat dimanfaatkan untuk mengatasi fix-point to point dan biaya, serta menjadi model fleksibel multi point to multi point. Pesatnya perkembangan dunia jaringan komputer akhir-akhir ini, memicu berkembangnya teknologi baru yang memanfaatkan teknologi jaringan komputer sebagai media untuk mewujudkan impian manusia akan sebuah aplikasi pengoperasian peralatan dari tempat lain yang sangat jauh tanpa harus berada di tempat tersebut.

Permasalahan yang sering muncul yaitu perbedaan parameter yang dimiliki (Masruroh \& Prasetyorini, 2015), perbedaan monitoring (Pradikta, Pradikta, Affandi, \& Setijadi, 2013) KKKS termasuk karakter pengisisan data. Khusus untuk KKKS dengan produk minyak terdapat flushing yang seharusnya tidak dimasukkan sebagai volume lifting. Nilai flushing ini berbedabeda untuk tiap KKKS sehingga perlu penyamaan persepsi dengan KKKS tentang tata cara recording data termasuk waktu pengisian database. Masih terdapat perbedaan waktu di titik CTP, waktu di Poller Migas Control Center dan waktu di Database Server sehingga ada sebagian data flowrate yang terisi tetapi belum sempat ditampilkan di web.

Dalam penelitian ini melakukan riset tentang Sistem Monitoring Volume Lifting Minyak dan Gas Bumi Berbasis SCADA (Supervisory Control and Data Acquisition) atau biasa dikenal dengan Online Realtime System merupakan suatu sistem yang dibangun dan diimplementasikan di titik Custody Transfer Point (CTP) dan melakukan akuisisi data secara online realtime dari setiap titik pantau, sehingga data-data tersebut dapat dipantau dan dimonitor secara realtime.

Tujuan dari penelitian ini untuk peningkatan efektifitas dan efisiensi pengelolaan usaha dan tata niaga minyak dan gas bumi, khususnya dalam hal monitoring volume lifting minyak dan gas bumi. Pemasangan sistem monitoring yang merupakan integrasi dari sejumlah aplikasi perangkat lunak, perangkat keras serta sejumlah prosedur yang mampu melakukan verifikasi serta penelusuran terhadap kebenaran laporan volume lifting yang disampaikan oleh pihak KKKS. Stabilitas akses dan akuisisi data melalui sistem integrasi data produksi dan lifting minyak dan gas bumi secara online realtime. Adanya penerapan sistem monitoring volume lifting minyak dan gas bumi secara online dan realtime di 33 CTP (Costudy Transfer Point). Memperoleh data atau informasi volume produksi dan volume lifting minyak dan gas serta pembagiannya sesuai dengan masingmasing daerah penghasil secara transparan, akurat dan cepat.

\section{BAHAN DAN METODE}

\section{A. Topologi Jaringan}

Berikut topologi jaringan Sistem Monitoring Lifting Minyak dan Gas Bumi.

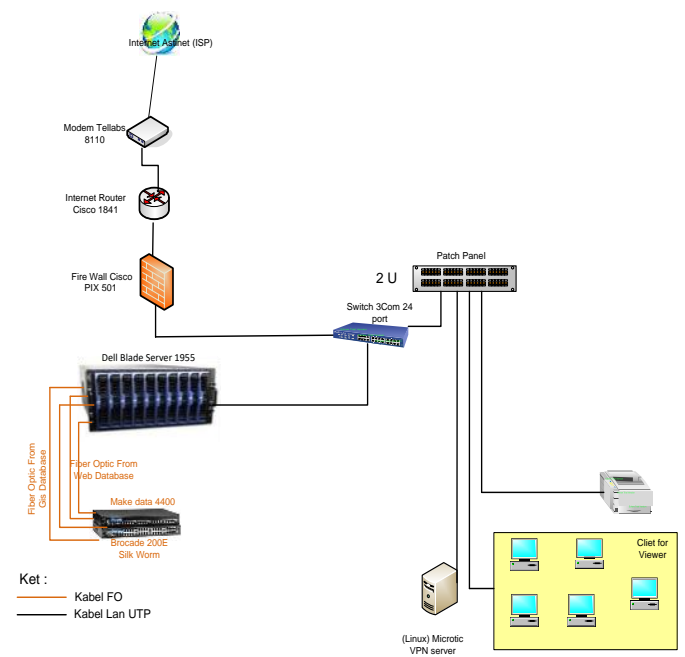

Sumber : (PT.Astron-Optima, 2012)

Gambar 1. Topologi Jaringan Sistem Monitoring Volume Lifting Minyak dan Gas Bumi

\section{B. Arsitektur Jaringan \& Skema Jaringan}

Arsitektur jaringan yang digunakan pada Sistem Monitoring Volume Lifting Minyak dan Gas 
Bumi adalah operasi jaringan model Clinet-Server. Sistem operasi jaringan Client-Server memungkinkan jaringan untuk mensentralisasi fungsi dan aplikasi kepada satu atau lebih dedicated file server.

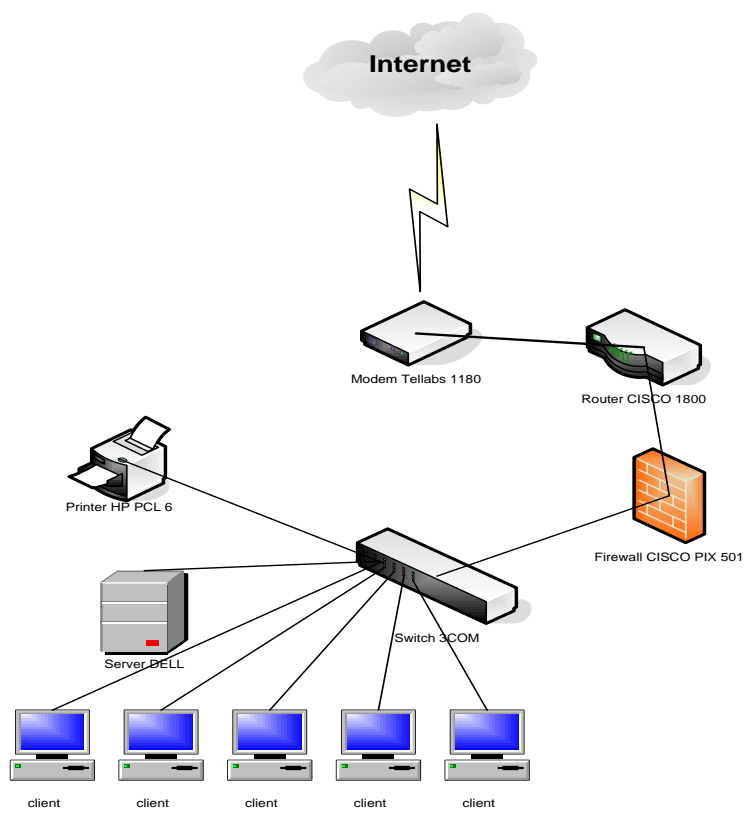

Sumber : (PT.Astron-Optima, 2012)

Gambar 2. Skema Jaringan Sistem Monitoring Volume Lifting Minyak dan Gas Bumi

\section{Keamanan Jaringan}

Keamanan jaringan pada Sistem Monitoring Volume Lifting Minyak dan Gas Bumi pada saat ini sudah cukup bagus, selain menggunakan perangkat Hardware Firewall Cisco PIX 501 series yang digunakan sebagai internet gateway dan melakukan fungsi NAT (Network Address Translation) yang memberikan akses IP private agar dapat masuk ke jaringan internet. Pada sistim ini juga tiap PC sudah terpasang antivirus McAfee yang selalu terupdate.

\section{Sistem SCADA (Supervisory Control and Data Acquisition)}

Di dunia industri, sistem otomatis sangat diminati karena dapat menjamin kualitas produk yang dihasilkan, memperpendek waktu produksi dan mengurangi biaya untuk tenaga kerja manusia. Salah satu pengendali yang paling popular, khususnya untuk sistem yang bekerja secara sekunsial, ialah Programmable Logic Controller (PLC). Berikut ini review PLC dan Otomasi Sistem

Dari kepanjangan PLC, kita dapat mengetahui definisi sederhana dari PLC itu sendiri.

1. Programmable
Dapat diprogram (software based).

2. Logic

Bekerja berdasar logika yang dibuat, logika disini biasanya menunjuk pada logika Boolean yang hanya terdiri dari 2 keadaan, ON atau OFF.

3. Controller

Pengendali (otak) dari suatu sistem.

Secara umum, cara kerja sistem yang dikendalikan PLC cukup sederhana.

a. PLC mendapatkan sinyal input dari input device.

b. Akibatnya PLC mengerjakan logika program yang ada di dalamnya.

c. PLC memberikan sinyal output pada output device.

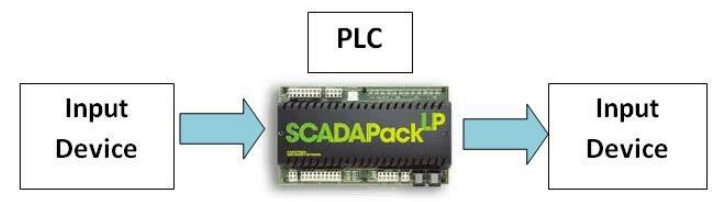

Sumber: (Wicaksono, 2012)

Gambar 3. diagram hubungan PLC dan input/output device

Dari penjelasan diatas, didapatkan definisi sebagai berikut :

1. PLC input device : benda fisik yang memicu eksekusi logika/program pada PLC. Contoh : saklar dan sensor.

2. PLC output device : benda fisik yang diaktifkan oleh PLC sebagai hasil eksekusi program. Contoh : motor DC, motor AC, solenoid dan lain-lain.

Pada bagian ini akan dijelaskan tentang definisi PLC. Menurut NEMA (National Electrical Manufacturers Association-USA) definisi PLC ialah "Alat elektronik digital yang menggunakan programmable memory untuk menyimpan intruksi dan untuk menjalankan fungsi-fungsi khusus seperti : logika, sequence (urutan), timing (pewaktuan), penghitungan dan operasi aritmatika untuk mengendalikan mesin dan proses." Definisi lain menyebutkan bahwa PLC ialah "Komputer industri khusus untuk mengawasi dan mengendalikan proses industri menggunakan bahasa pemrograman khusus untuk kontrol industri (ladder diagram), didesain untuk tahan terhadap lingkungan industri yang banyak gangguan (noise, vibration, shock, temperature, humidity)."

PLC terbagi dari beberapa komponen utama. Untuk memahaminya, perhatikan gambar yang 
menampilkan hubungan PLC dengan peralatan lain berikut ini :

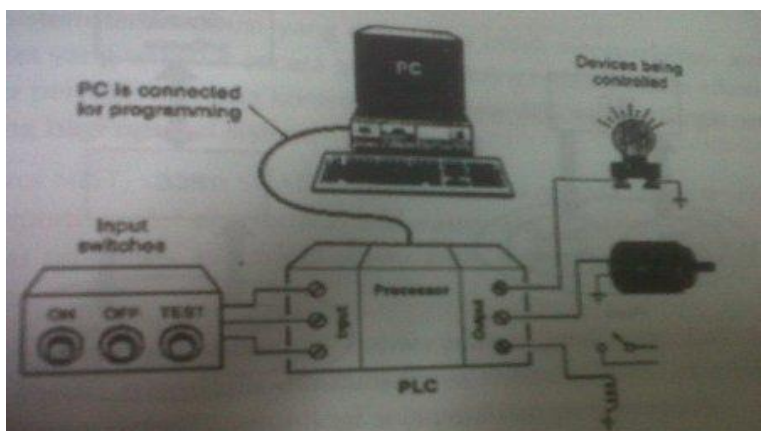

Sumber: (Wicaksono, 2012)

Gambar 4. hubungan PLC dengan peralatan lain

Dari gambar 4 di atas nampak bahwa PLC memiliki komponen yang terhubung dengan input device dan output device. PLC juga terhubung dengan PC untuk kebutuhan pemrograman (umumnya menggunakan RS 232 serial port). Secara umum PLC terbagi dalam beberapa komponen berikut :

1. Power Supply

2. Processor

3. Memory

4. Input and Output Device

5. Programming Device

Jika suatu plant atau sistem otomatis masih berukuran kecil, tingkat komplesitas rendah dan tidak memerlukan akurasi yang tinggi maka skema otomasi sistem dengan PLC saja sudah cukup. Namun, jika kompleksitas plant relative besar dan akurasi yang dibutuhkan dalam sistem relatif tinggi maka sangat diperlukan suatu sistem SCADA. Skema sistem SCADA sederhana yang diimplementasikan melalui program komputer seperti dibawah ini :

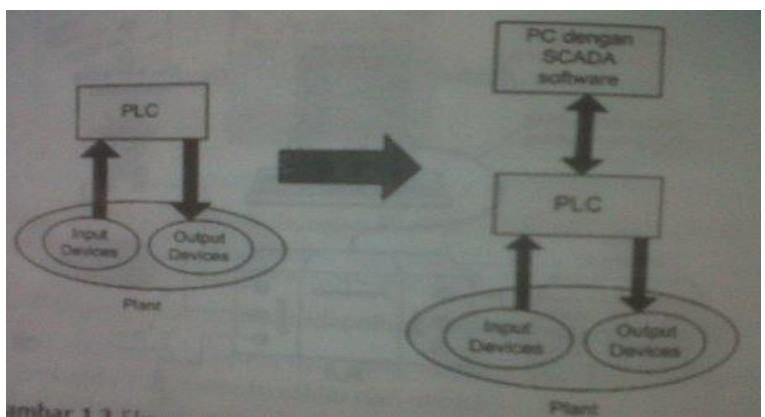

Sumber: (Wicaksono, 2012)

Gambar 5. Skema system SCADA sederhana dalam pengendalian sistem

HASIL DAN PEMBAHASAN

\section{A. Sistem Monitoring Volume Lifting Minyak dan Gas Bumi Berbasis SCADA (Supervisory Control and Data Acqucition).}

Sistem Monitoring Volume Lifting Minyak dan Gas Bumi Berbasis SCADA atau biasa dikenal dengan Online Realtime System merupakan suatu sistem yang dibangun dan diimplementasikan berbasiskan SCADA di titik Custody Transfer Point (CTP) dengan melakukan akuisisi data volume secara online realtime dari setiap titik pantau, sehingga data-data volume lifting tersebut dapat dipantau secara realtime melalui Migas Control Center. Proses ini dilakukan menggunakan SCADA Sistem, yaitu sistem yang dirancang untuk mengumpulkan data dan menampilkan pergerakan volume lifting secara Online Realtime di Migas Control Center. Data yang dikumpulkan akan disimpan dalam database untuk divisualisasikan kemudian ditransfer ke dalam sistem web.

Sistem ini dibangun untuk mendukung pengguna sistem (end user) dalam melakukan pengawasan terhadap realisasi volume lifting minyak dan gas bumi di setiap titik Custody Transfer Point (CTP) secara realtime. Hasil dari monitoring lifting secara realtime ini akan digunakan sebagai salah satu referensi dalam melakukan monitoring lifting di KKKS.

SCADA adalah sebuah akronim untuk Supervisory Control and Data Acquisition.

a. Data Acquisition merupakan proses mendapatkan informasi dari proses-proses yang terdistribusi secara luas.

b. Supervisory Control adalah menghitung dan memberikan instruksi-instruksi pengendalian untuk fasilitas-fasilitas proses yang letaknya jauh (remote facilities).

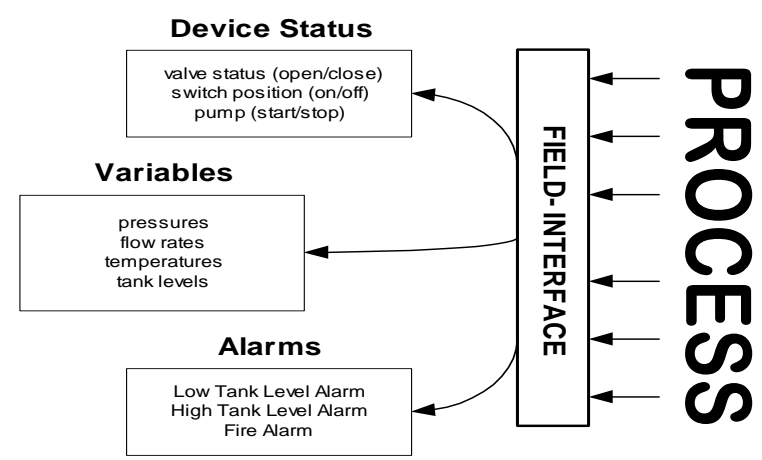

Sumber : (PT.Astron-Optima, 2012)

Gambar 6. Rancangan Konsep Dasar Sistem Monitoring Volume Lifting Minyak dan Gas Bumi Berbasis SCADA

Konsep sistem monitoring lifting pada dasarnya merupakan kegiatan pengawasan terhadap realisasi volume lifting serta perhitungan 
alokasi lifting untuk setiap daerah penghasil. Sistem monitoring ini merupakan integrasi dari penggunaan teknologi akuisisi data secara onlinerealtime serta teknologi berbasis web yang memungkinkan untuk mengirim data volume secara online. Di samping pemanfaatan berbagai teknologi informasi dan komunikasi, sistem ini juga ditunjang dengan sejumlah pedoman operasional yang meliputi beberapa prosedur pelaksanaan yang terkait langsung dengan kegiatan monitoring.

Penggunaan teknologi tersebut di atas ditujukan untuk membantu proses akuisisi data, pengolahan data dan proses pelaporan volume produksi dan lifting minyak dan gas bumi kepada semua stakeholder. Sedangkan melalui penerapan sejumlah prosedur, maka implementasi sistem ini juga ditunjang dengan beberapa aktifitas berupa kegiatan validasi/verifikasi data serta kegiatan audit lapangan untuk membuktikan kebenaran hasil perhitungan setiap KKKS.

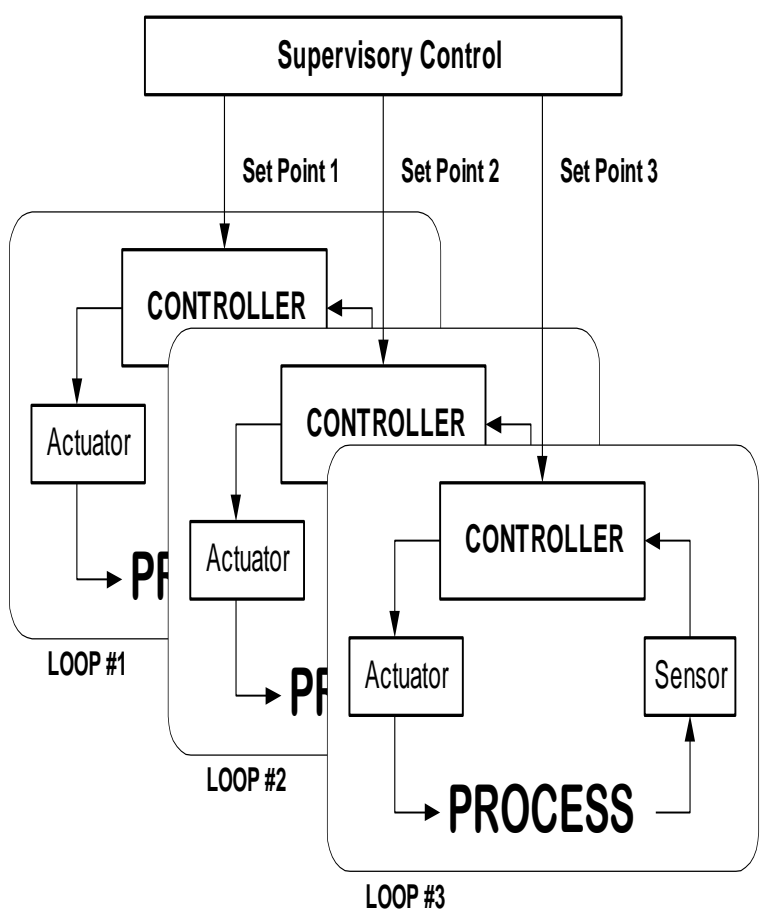

Sumber : (PT.Astron-Optima, 2012)

Gambar 7. Rancangan Alur Proses Implementasi dari Supervisory Control

Implementasi dari supervisory control ditujukan untuk :

a. Manajemen titik pengaturan (set point) untuk beberapa sistem kendali

b. Optimalisasi untuk memperoleh titik operasi yang terbaik
Menggunakan algoritma-algoritma kontrol lanjut. (cascade controller, ratio controller, override control, dan lain-lain).

\section{B. Data Sistem}

Pada gambar di bawah ini terlihat secara lebih rinci data-data volume yang dibutuhkan, meliputi volume produksi dan volume lifting serta metode akuisisi data tersebut.

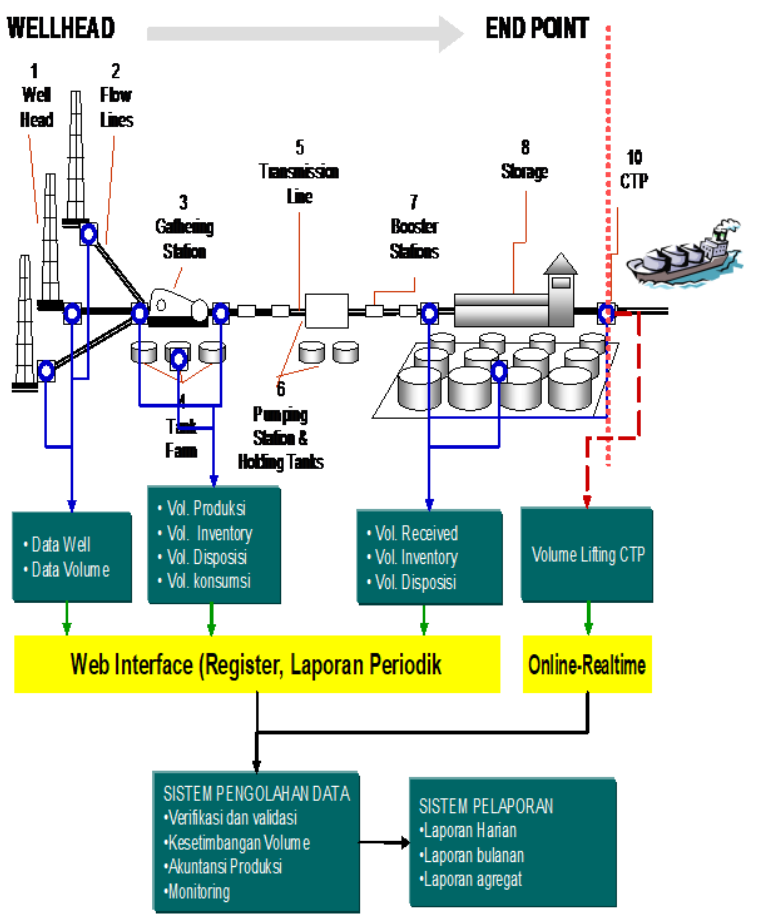

Sumber : (PT.Astron-Optima, 2012)

Gambar 8. Rancangan Sistem Akusisi Data dan Integrasi

Akuisisi dan Integrasi data secara efisien memungkinkan untuk peningkatan usaha dan tata niaga migas yang melibatkan banyak stakeholder termasuk pihak KKKS dan pihak Pemerintah Daerah yang memiliki kepentingan dalam pendapatan daerah sebagaimana diatur dalam undang-undang. Dengan adanya data akuisisi volume lifting yang dilakukan terus-menerus secara berkesinambungan dan terintegrasi secara nasional, maka pemerintah daerah bersama dengan pemerintah pusat dapat memantau serta mengelola pendapatan daerah serta pusat secara lebih akurat dan dapat membuat perencanaan serta melaksanakan pembangunan dengan lebih baik dan akurat.

Dari penjelasan konsep sebagaimana dijelaskan di atas, maka dapat disusun usulan platform aplikasi (software) secara umum 
sebagaimana terlihat pada diagram blok di bawah ini.

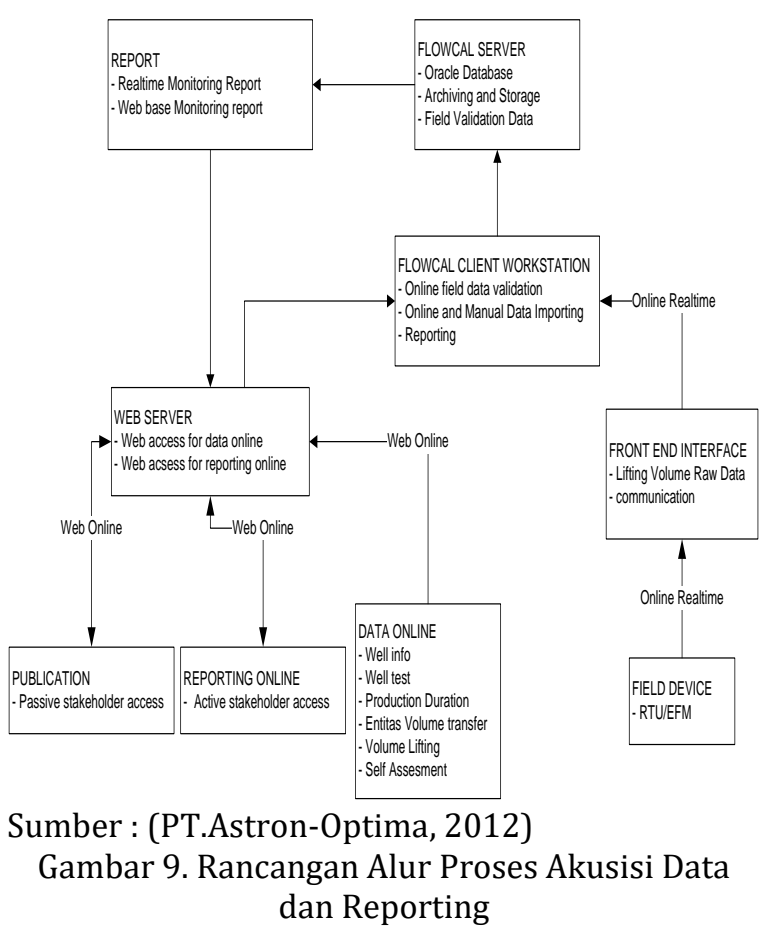

Terlihat jelas pada diagram di atas bahwa melalui kombinasi akuisisi data secara online realtime dengan menggunakan teknologi sistem SCADA dengan teknologi web akan dapat mengumpulkan data-data yang diperlukan dalam perhitungan volume lifting sebagai dasar dari pengawasan (controlling) terhadap laporan lifting yang disampaikan setiap bulannya oleh pihak KKKS.

Selanjutnya dengan menggunakan angka volume hasil monitoring akan dilakukan validasi terhadap laporan lifting dengan menetapkan nilai ambang batas yang telah disepakati oleh ditjen migas.

Jika masih dalam ambang batas maka secara otomatis laporan lifting kontraktor dinyatakan valid, jika diluar ambang batas, maka akan dilakukan klarifikasi atau audit untuk memastikan penyebab penyimpangan tersebut.

\section{Proses Tapping Data}

Kegiatan ini meliputi komunikasi antara Migas Control Center dengan lapangan atau CTP yang di hubungkan dengan sistem komunikasi Telkom VSAT. Adapun mekanisme perolehan data tersebut dapat dilihat seperti gambar dibawah ini :

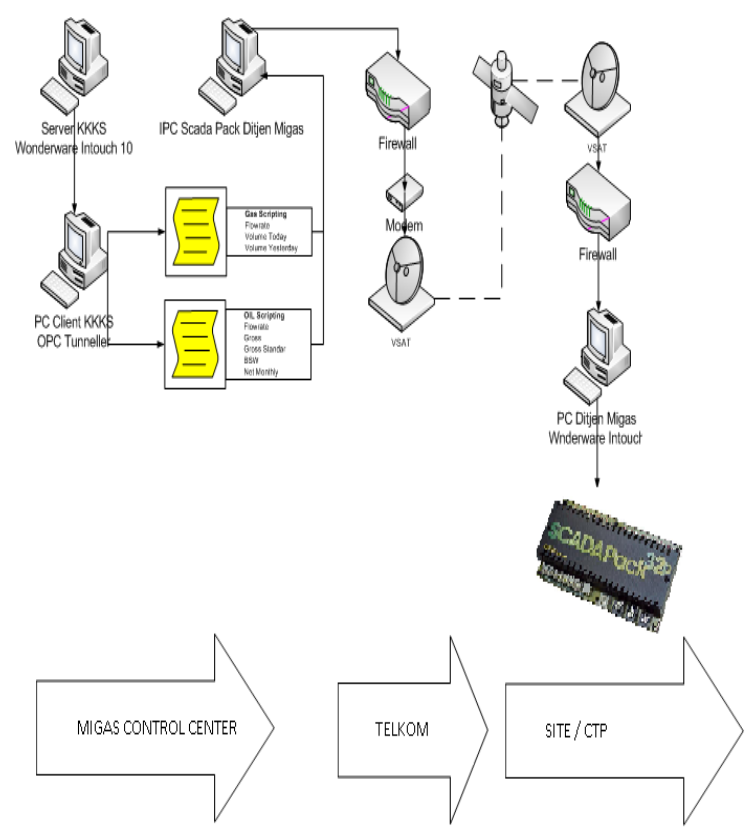

Sumber : (PT.Astron-Optima, 2012)

Gambar 10. Rancangan Alur mekanisme perolehan data dari CTP ke Migas Control Center

Keterangan gambar 10 diatas:

a. Komputer HMI milik dari KKKS di integrasikan dengan komputer HMI Migas.

b. Setelah kedua komputer tersebut terhubung maka proses tapping / capture data setelah kedua komputer tersebut terhubung maka proses tapping/capture data dilakukan dengan cara penyeragaman Value Tage name dengan Name text yang berbeda dengan KKKS. Hal ini di lakukan untuk mengantisipasi adanya indentifikasi yang double/ganda pada HMI.

c. Setelah data masuk ke komputer HMI Migas, komputer yang telah terhubung denga VSAT Telkom yang terhubung langsung dengan pusat data yang di Migas Control Center (MCC).

d. Data dikirim ke MCC yang melewati sentral Telekomunikasi Jakarta dan di sambungkan ke receiver yang ada di Gedung Migas dan bermuara pada Modem VSAT yang berada di ruang Server Lt. 6.

e. Data di teruskan ke Poller A dan Poller B dengan media penyimpanan SQL Server 2000.

Tahap display data dan penyesuaian data dengan CTP/Lapangan :

a. Proses ini dimulai dari pengumpulan data hardcopy atau data lifting perhari dari masing-masing CTP. Data pembanding yang 
berasal dari lapangan biasanya diperoleh dari bagian finance. Data tersebut akan dikirimkan secara terus menerus ke pihak Migas Control Center secara email atau fax. Pengiriman dilakukan paling lambat tanggal 15 pada bulan berikutnya. Salah satu contoh data adalah sebagai berikut :

b. Proses penarikan data dari SQL Server 2000 yang telah diperoleh di Migas Control Center. Data yang diperoleh harus terlebih dahulu di pilah-pilah berdasarkan masing-masing CTP dan tanggalSumber : PT. Astron Optima

c. Secara Umum Taping data dilakukan melalui IPC MIGAS atau RTU SCADAPACK. Untuk KKKS dengan produk Oil data yang diambil antara lain Flowrate, Gross Volume dan Net Volume. Sedangkan untuk KKKS dengan produk Gas, data yang ditaping yaitu Flowrate, Volume Today, Volume Yesterday dan Volume Monthly. Protokol yang digunakan akan mengikuti ketersediaan port komunikasi yang disyaratkan KKKS, misalnya menggunakan TCP/IP atau Modbus RS232/485. Data tersebut kemudian diteruskan ke Migas Control Center melalui VSAT.

\section{Pemeliharaan Data}

Data yang telah diambil dari berbagai CTP akan dikumpulkan dan diolah sedemikian rupa mulai dari penyeragaman skala, satuan/unit, nilai maksimum dan nilai minimumnya. Selain itu proses rekam data membutuhkan script tersendiri untuk masing-masing CTP yang akan memberikan perintah pencatatan maupun perhitungan. Proses ini berguna terutama untuk KKKS yang tidak memiliki parameter yang dibutuhkan Migas, sehingga dibutuhkan perhitungan terlebih dahulu dari parameter yang ada. Seperti contoh untuk KKKS dengan produk Gas yang tidak memiliki angka Volume Yesterday, maka data Volume Totalizer yang diambil harus diolah terlebih dahulu sehingga menghasilkan angka Volume Yesterday.

Maka dibuat perintah untuk menghitung volume totalizer sehingga diperoleh nilai Volume Yesterday sebesar (Y-X).

\section{E. Database}

Untuk penyimpanan database dari Wonderware Intouch digunakan software Microsoft SQLServer 2000 dan InSQL 9.0 dengan struktur pengisian data seperti terlihat pada gambar 11 .

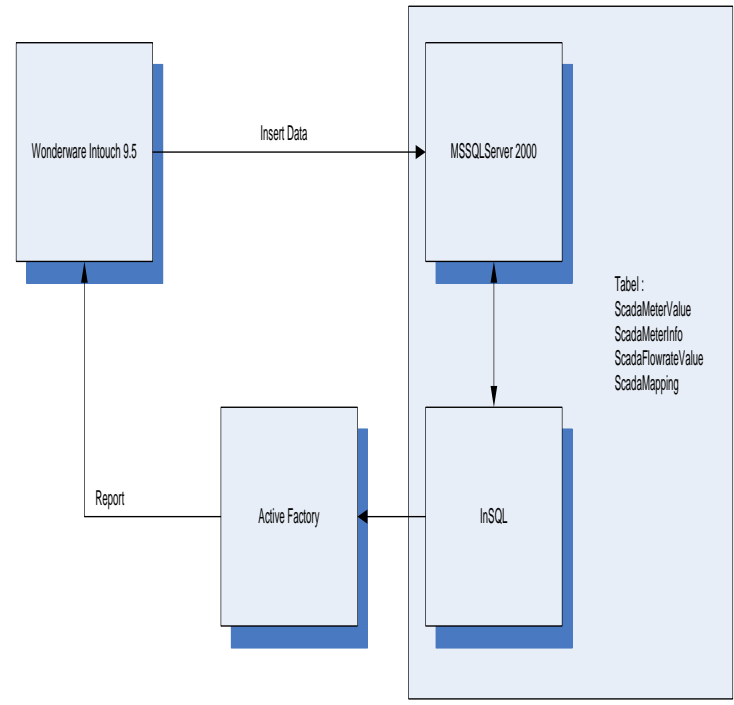

Sumber : (PT.Astron-Optima, 2012)

Gambar 11. Rancangan Alur proses pengisian data dari Wonderware Intouch ke MSSQL Server

Data yang diambil dari masing-masing titik CTP dimasukkan ke dalam table ScadaMeterValue, sementara table ScadaMeterInfo berfungsi untuk menyimpan data informasi titik CTP meliputi lokasi dan Nama KKKS yang bersangkutan. Tabel ScadaMaping dan ScadaFlowrateValue berfungsi sebagai interface ke sistem web. Waktu penyimpanan data diatur dalam perintah wonderware Intouch. Permasalahan yang muncul biasanya terdapat perbedaan waktu di titik CTP, waktu di Poller Migas Control Center dan waktu di Database Server sehingga ada sebagian data flowrate yang terisi tetapi belum sempat ditampilkan di web. Oleh karena itu perlu disesuaikan waktu antara Poller dan Database Server.

\section{F. Pelaporan (Reporting)}

Untuk sistem pelaporan di HMI Wonderware terdapat dua jenis pelaporan yaitu laporan harian dan laporan detail masing-masing titik CTP. Untuk laporan harian digunakan untuk memantau nilai lifting per hari tiap-tiap CTP. Laporan harian mencakup volume lifting semua CTP yang sedianya dicetak ke dalam bentuk hardcopy setiap hari. Sedangkan laporan detail digunakan untuk melihat volume lifting secara terperinci dalam batas waktu yang dapat ditentukan oleh pengguna. Tampilan laporan detail menggunakan ActiveX HistClientActiveDataGrid yang menampilkan data dari Ms SQLServer melalui InSQL. Permasalahan yang sering muncul yaitu delay antara database server dengan Poller yang tidak mungkin dihilangkan melainkan diperkecil. 


\section{KESIMPULAN}

Setelah melakukan pemasangan Sistem Monitoring Volume Lifting Minyak dan Gas Bumi Berbasis SCADA (Supervisory Control and Data Acqusition) maka dapat diambil kesimpulan sebagai berikut: 1) Diperoleh data yang akurat sebagai pembanding antara volume lifting yang dimonitor secara online realtime dengan volume lifting yang dilaporkan KKKS. 2) Diperoleh informasi volume lifting minyak dan gas bumi yang akurat pada titik-titik pantau secara online realtime. 3) Melalui pemanfaatan fungsi system monitoring volume lifting minyak dan gas bumi berbasis SCADA dapat diperoleh data sebagai dasar bagi perhitungan jumlah dana bagian daerah penghasil migas yang transparan dan sesuai dengan ketentuan. 4) Dengan teknologi VSAT data yang dikirimkan ke Migas Control Center dari tiap site / CTP akan aman dan cepat. Untuk pengiriman data menggunakan teknologi VSAT, dimana teknologi ini menggunakan topologi star, sedangkan untuk koneksinya menggunakan jenis koneksi point to multipoint. Saran yang bisa diberikan untuk pengembangan Sistem Monitoring Volume Lifting Minyak dan Gas Bumi Berbasis SCADA (Supervisory Control and Data Acqusition) adalah dengan mengganti teknologi pengiriman data yang menggunakan teknologi VSAT dengan teknologi VPN (Virtual Private
Network) karena data yang dibutuhkan untuk sistem ini tidak begitu banyak/besar.

\section{REFERENSI}

Masruroh, N. A., \& Prasetyorini, A. V. (2015). Model Penjadwalan Pengiriman Pasokan pada Strategi Multi-Supplier dengan Variasi Harga dan Lead Time untuk Permintaan Stokastik. Jurnal Teknik Industri, 17(1), 3546. https://doi.org/10.9744/jti.17.1.35-46

Pradikta, R., Pradikta, R., Affandi, A., \& Setijadi, E. (2013). Rancang Bangun Aplikasi Monitoring Jaringan dengan Menggunakan Simple Network Management Protocol. Jurnal Teknik ITS, 2(1), A154-A159. https://doi.org/10.12962/j23373539.v2i1.2 265

PT.Astron-Optima. (2012). Lembar Kerja PT. Astron Optima. Jakarta.

Wicaksono, H. (2012). SCADA Software dengan Wonderware Touch Dasar-Dasar Pemrograman (1st ed.). Yogyakarta: Graha Ilmu. 